\title{
ANALISIS KINERJA PT MATAHARI DEPARTMENT STORETBK PASKA DIMULAINYA PANDEMI COVID-19
}

\author{
Sunaryono \\ Sunaryono@yahoo.com \\ POLITEKNIK PUTRA BANGSA PONTIANAK
}

\begin{abstract}
This research aims to determine the financial performance of PT Matahari Department Store Tbk b efore and after the Covid-19 pandemic was started so that it can be observed the increase or decrease after the Covid-19 pandemic was started. The data used are the financial statements of the posted-Pandemi Covid-19 of PT Matahari Department Store Tbk before the covid-19pandemicwas started in the January-December 2019 and after the covid-19 pandemic was started in the January - December 2020 period. Data analysis using Du Pont System Analysis. The results showed an increase in the financial ratios before the covid-19 pandemic started and after the covid-19 pandemic started. This is indicated by the achievement of an increase in the percentage of Return on Investment, Return on Assets, Cash Ratio, Current Ratio, Collection Period, Inventory Turn Over, Total Asset Turn Over, and Total Equity so that the increase can prove that the research hypothesis proposed that after a covid-19 pandemic is proven to experience efficiency and decrease its financial performance.
\end{abstract}

Key word: Financial Performance, Covid-19Pandemic, Rasio keuangan, Cash ratio, Current Ratio.

\section{PENDAHULUAN}

Dalam masa pandemi, pemerintahIndonesia memutuskan untukmemperhatikan tiga sektor, yaitukesehatan, sektor riil dan perbankan.Pandemi Covid-19 sudah dipastikan akan menimbulkan permasalahan di sektor riil atau duniausaha yang sangat signifikan. Hal initentu saja bisa terjadi, dikarenakan sektorriil merupakan sektor usaha yang langsung berhubungan dengan konsumen.

PT. Matahari Department Store tbk merupakan salah satu perusahan dagang yang begera $\mathrm{k}$ di bidang perdangangan pakaian, yang dalam penelitian ini akan di lakukan analisis seberapa besar persentase kinerja dari perusahaan ini yang berkurang setelah terjadinya pandemi korona.

Berdasarkan penjelasan latar belakang di a ta $\mathrm{s}$ maka permasalahannya adalah apakahkinerja keuangan PT Matahari Department Store Tbk periode Januari-Desember 2020 menjadi lebih rendah dari pada kinerja keuangan PT. Matahari Department Store periode Januari-Desember 2019.

Ilhami1 \& Husni Thamrin (2021) dalam penelitiannya melakukan analisis dampak covid -19 terhadap rasio keuangan perbankan, dan dari hasil penelitian tersebut dihasilkan kesimpulan bahwa perbankan syariah mampu bertahan di masa pandemi, dari hasil kesimpulan diatas, penelitian ini akan melakukan analisis mengenai dampak pandemi covid-19 terhadap salah satu perusahaan yang bergerak dibidang sektor riil. PT. Matahari Departement Store Tbk merupakan salah satu perusahaan yang bergerak di sektor riil yang akan di lakukan analisis terkait kinerja keuangannya sebelum dan sesudah dimulainya pandemi covid19pada awal tahun 2020 .

Penelitian ini menganalisis Return On Asset (ROA) , Return On Equity (ROE) dan Du Pont Analysis. Hasil penelitianmenunjukkan bahwa ratarata perusahaan di Industri distribusi makanan di Korea menunjukkankinerja keuangan yang semakin meningkat. Penelitian Doorasamy (2016) untuk mengukur kinerja keuangan dengan menggunakan Dupont System analyisis . Hasil temuan (Elita et al.,2015) kinerja keuangan PT Semen Gresik selama periode 2009-2013 cenderung mengalamipenurunan. Dari hasil penelitianpenelitian tersebut menunjukkan bahwa rata -rata kinerjakeuangan perusahaan bisa di ukur dengan du pont system yang menggunakan beberapa rasio, dari perhitungan diatas penelitian ini akan mendalami seberapa besar perubahan kinerja keuangan paska pandemi covid-19pada PT Matahari Department 
Store Tbk, apakah tetap bisa bertahan seperti tahuntahun sebelumnya atau mengalami kerugian yang signifikan. Penelitian ini berbeda denganpenelitian sebelumnya tentang obyek dan ala $\mathrm{t}$ analisisnya. Penelitian ini bertujuan untukmenganalisis efisiensi kinerja keuangan PT Matahari Department Store Tbk periode 2020 paska Pandemi Covid-19.

\section{TINJAUAN TEORETIS}

Kinerja keuangan merupakan gambaran kondisi keuangan perusahaan pada periodetertentu baik menyangkut aspek penghimpunan dana maupun penyaluran dana yang biasanyadiukur dengan indikator rasio keuangan (Sartono, 2012: 113-115). Menurut Weston (2009:215)kinerja keuangan adalah kemampuan perusahaan untuk mempertahankan dan memperbaikikeuangan perusahaan, sehingga tidak mengarahkan perusahaan kepada risiko keuangan yanglebih besar.

Dalam melakukan analisis kinerja keuangan manajer keuangan dapatmembandingkan rasio a ta $u$ prestasi keuangan satu periode perusahaan dibandingkan rata-ratarasio industrinya. Kinerja keuangan sudah menjadi salah satu faktor yang menunjukkan efektifitasdan efisiensi suatu organisasi dalam mencapai tujuan organisasi. Efektifitas apabila manajemenmemiliki tujuan yang tepat atau suatu alat yang tepat untuk mencapai tujuan.

Efisiensi diartikansebagai rasio perbandingan antara masukan dan keluaran yaitu dengan masukan terntentumemperoleh keluaran yang optimal. Analisis keuangan yang mencakup analisis rasio keuangan,analisis kelemahan dan kekuatan di bidang finansial akan sangat membantu dalam menilaiprestasi manajemen masa lalu dan prospeknya di masa datang. Dengan analisis keuangan inidapat diketahui kekuatan serta kelemahan yang dimiliki oleh seorang business entreprise. Rasiotersebut dapat memberikan indikasi apakah perusahaan memiliki kas yang cukup untukmemenuhi kewajiban finansialnya, besarnya piutang yang cukup rasional, efisiensi manajemenpersediaan, perencanaan pengeluaran investasi yang baik, dan struktur modal yang sehatsehingga tujuan memaksimumkan kemakmuran pemegang saham dapat dicapai.

Kinerjakeuangan yang diukur antara lain profitabilitas , efisiensi , pertumbuhan ekonomi , fullemployment, dan equity. Profitabilitas merupakan kemampuan suatu perusahaan/industri untukmenghasilkan keuntungan dari keseluruhan modal yang digunakan. Ukuran untuk mengetahuitingkat keuntungan diantaranya a dala $\mathrm{h}$ return on assets, return on equity, return on investment, price/earning ratio

\section{METODE PENELITIAN}

Data yang dipakai pada penelitian ini adalah data sekunder. Data sekunder mengacupada informasi yang diperoleh dari tangan kedua oleh peneliti yang berkaitan dengan variabel(Sekaran, 2006). Data sekunder yang digunakan adalah laporan keuangan PT Matahari Department Store Tbk periode2019 hingga Desember 2020 antara lain laporan laba rugi perusahaan dan neraca tahunanperusahaan. Selain itu penelitian ini menggunakan data dividen dan harga saham perusahaanserta tingkat suku bunga bulanan sertifikat bank indonesia periode 2019 dan 2020

Rasio keuangan yang digunakan dalam metode Du Pont System (Sartono,2012)meliputi : Rasio Profitabilitas (Net Profit Margin), Rasio Aktivitas (Total Assets Turn Over),Perhitungan metode Dupont System meliputi Return on Investmen (ROI) dan Return on Equity(ROE) dengan Debt Ratio dan Multiplier Equity. Teknik analisis kinerja keuangan denganmenggunakan metode Du Pont System (Sartono,2012). Adapun langkah- langkah yangdilakukan adalah mengitung rasio - rasio keuangan yaitu Rasio Likuiditas dengan menghitungNWC (Net working Capital), CR (Current Ratio) dan QR (quick Ratio)

Untuk menghitung rasio keuangan diatas perlu rumus yang sudah ditetapkan untuk masing-masing rasio, rumus tersebut antar lain sebagai berikut :

Rasio Liquiditas dengan menghitung NWC, Current Ratio dan Quick Ratio, untuk Rumus untuk menghitung NWC adalah sebagaiberikut:

\section{NWC=AktivaLancar - Hutang Lancar}

Rumus untuk menghitung Current ratio adalah sebagaiberikut:

$$
\mathrm{CR}=\frac{\text { Aktiva Lancar }}{\text { Hutang Lancar }} \times 100 \%
$$

Rumus untuk menghitung Quick Ratio adalah sebagaiberikut

$$
\mathrm{QR}=\frac{\text { Aktiva Lancar-Persediaan }}{\text { Hutang Lancar }} \times 100 \%
$$

Ratio Aktivitas dengan menghitung ITO, AAI,FATO dan TATO, Rumus untuk menghitung ITO (Inventory Turnover ratio) 


$$
\text { ITO }=\frac{\text { Harga Pokok Penjualan }}{\text { Rata-rata Persediaan }} \times 1 \text { kali }
$$

Rumus untuk menghitung AAI (Average Age of Inventory)

$$
\mathrm{AAI}=\frac{360}{\text { Inventory Turnover }}
$$

Rumus untuk menghitung FATO (Fixed Asset Turnover)

$$
\text { FATO }=\frac{\text { Penjualan }}{\text { Aktiva Tetap }} \times 1 \text { kali }
$$

Rumus untuk menghitung TATO (Total Asset turnover)

$$
\text { TATO }=\frac{\text { Penjualan }}{\text { Total Aktiva }} \times 1 \text { kali }
$$

Rasio Solvabilitas dengan menghitung Debt Ra tio, Debt Equity Ratio, DTCR. Rumus untuk menghitung DR (Debt Ratio) Sebagai berikut :

$$
\text { DR }=\frac{\text { Total Hutang }}{\text { Total Aktiva }} \times 100 \%
$$

Rumus untuk menghitung Debt Equity Ratio sebagaiberikut

$$
\text { DER }=\frac{\text { Hutang Jangka Panjang }}{\text { Modal Sendiri } x} \times 100 \%
$$

Rumus untuk menghitung DTCR (Debt to Total Capitalization Ratio )

$$
\text { DTCR }=\frac{\text { Hutang Jangka Panjang }}{\text { Hutang Jangka Panjang+Modal Sendiri }} \times 100 \%
$$

Terakhir adalah menghitung Rasio Profitabiklitas yang terdiri dari GPM (Gross Profit Margin), OPM (Operating Profit Margin) dan NPM (Net Profit Margin), rumus untuk menghitung GPM (Gross Profit Margin ) sebagaiberikut :

$$
\mathrm{GPM}=\frac{\text { Penjualan }-H P P}{\text { Penjualan }} \times 100 \%
$$

Rumus untuk menghitung OPM (Operating Profit Margin)

$$
\mathrm{OPM}=\frac{\text { Laba Operasi }}{\text { Penjualan }} \times 100 \%
$$

Rumus untuk menghitung NPM (Net Profit Margin)

$$
\mathrm{NPM}=\frac{\text { Laba bersih sesudah pajak }}{\text { Penjualan }} \times 100 \%
$$

Net Profit Margin merupakan salah satu rasio yang paling penting dalam menilai seberapa besar kemampuan perusahaan untuk menghasilka $\mathrm{n}$ la bar dari penjualan yang ada, hasil dari NPM ini di tulis dalam persentase.

Setelah menghitung rasio-rasio tersebut kemudian peneliti melakukan analisis denganmenggunakan $\mathrm{Du}$ Pont System dengan langkah sebagaiberikut:

Menghitung Return On Investment yaitu ROI = NPM x TATO x 100\%. Jika nilai ROImenunjukkan kenaikan merupakan indikator bahwa kem ampuan manajemen perusahaanmengalami kenaikan dala $\mathrm{m}$ melakukan pengelolaan harta atau asset untuk menghasilkan labaoperasi demikian sebaliknya jika ROI mengalami penurunan, hal ini merupakan indikatorbahwa kemampuan manajemen mengalami penurunan dalam melakukan pengelolaan harta atauasset untuk menghasilkan laba operasi.

$$
\mathrm{ROE}=\frac{\text { Return On Investment }}{1-\text { Debt ratio }} \times 100 \%
$$

Jika nilai ROE mengalami kenaikan hal ini merupakan indikator bahwa tingkat penghasilanbersih yang diperoleh perusahaan atau modal yang diinvestasikan mengalami kenaikan,demikian sebaiknya jika ROE menga la m i penurunan, hal ini menunjukkan indikator bahwapenghasilan bersih yang diperoleh perusahaan mengalami penurunan

\section{HASIL PENELITIAN DAN PEMBAHASAN}

Penelitian ini dilakukan untuk menganalisis kinerja keuangan PT Matahari Department Store Tbkpaska dimulainya masa pandemi covid-19 di indonesia dan sebelum dimulainya masa pandemi covid-19 di indonesia atau pada periode 2019 2020 . 
Untuk membuktikan hipotesis pertama yangmenyatakan bahwa setelah pandemi covid -19 perusahaan mengalami penurunan penjualan yang signifikan sehingga kinerja keuangan menurun maka digunakan metode DuPont Analysis(Sartono,2012).

Data pembanding kinerja keuangan sebelum dan paska pandemi covid PTMa tahari Department Store Tbk disajikan dalam tabel 1 berikut:.

Tabel 1.0

Kinerja Keuangan PT. Matahari Dept Store Tbk Per 31 Desember 2020

\begin{tabular}{|l|c|c|}
\hline Kinerja & $\begin{array}{c}\text { Paska } \\
\text { Pandemi } \\
\text { Covid-19 } \\
\text { (LK 2020) }\end{array}$ & $\begin{array}{c}\text { Sebelum } \\
\text { Pandemi } \\
\text { Coviod-19 } \\
\text { (LK 2019) }\end{array}$ \\
\hline ROE & $-150 \%$ & $78 \%$ \\
\hline ROI & $-14 \%$ & $28 \%$ \\
\hline Cash Ratio & $18 \%$ & $43 \%$ \\
\hline Current Ratio & $56 \%$ & $106 \%$ \\
\hline ITO & 2,02 & 3,45 \\
\hline TATO & 0,77 & 2,13 \\
\hline TMS & $9,20 \%$ & $36,14 \%$ \\
\hline NPM & $-18,04 \%$ & $13,30 \%$ \\
\hline
\end{tabular}

Sumber : Laporan Keuangan 2020 ( Diolah )

Analisis Profitabilitas Terhadap Investasi Sebelum dan Paska dimulainya Pandemi Covid19

Return on Investment (ROI) PT Matahari Department Store Tbk pada tahun 2019 mencapai $28 \%$. Adapuntahun 2020menurun drastis hingga mencapai angka $-14 \%$. Return on Investment (ROI)sebagai perbandingan antara EBITDA dengan Capital Employed digunakan untuk menganalisiskeseimbangan antara laba dengan dana yang telah diinvestasikan untuk kegiatan operasiperusahaan. Menurunnya angka Return on Investment (ROI) dari tahun 2019 ke tahun 2020sebesar $42 \%$ artinya dari dana yang diinvestasikan sebesar Rp1.746 Triliun di tahun 2019mengalami penurunan sebesar sebesar $42 \%$. Return on Equity (ROE) PTMatahari Department Store Tbk tahun 2019 mencapai 78\%.Adapun di tahun 2020turun drastis menjadi $-150 \%$.

Return on Equity (ROE) merupakan salah satu profitability ratio yangdigunakan untuk mengukur kemampuan perusahaan dalam menghasilka $\mathrm{n}$ la ba dari investasipemegang saham di perusahaan. Penurunan capaian Return on Equity (ROE) dari tahun 2019 ketahun 2020 sebesar 228\% artinya dari dana yang diinvestasikan para pemegang saham sebesarRp. 280,46 Milyar atau menurun dari 325,04 milyar di tahun 2019mengalami kerugian yang drastis dari tahun sebelumnya sebesar $150 \%$.

\section{Analisis Perputaran Total Aktiva Sebelum dan Paska dimulainyaPandemi Covid-19}

Total Asset Turn Over (TATO) PT Matahari Department Store Tbkmengalami perubahan yang signifikan, pada tahun 2019 nilai TATO nya berjumlah 2,13x menjadi hanya 0,77 kali pada tahun 2020. Total Asset Turn Over (TATO

)merupakan merupakan Activity Ratio untuk menilai efektifitas penggunaan dana yang tertanamdalam jumlah aset dalam rangka menghasilkan pendapatan. Total Asset Turn Over (TATO)dihitung dengan membandingkan total pendapatan dengan Capital Employed. Kenaikan capaianTotal Asset Turn Over (TATO) dari tahun 2019 sebesar 2,13 kali ke tahun 2020menjadi 0,77, artinya mengalami penurunan capaianhingga $36,15 \%$.

\section{Analisis Tingkat Perputaran Persediaan Sebelum dan Paska Pandemi Covid-19}

Inventory Turn Over (ITO) PT Matahari Department Store Tbk pada tahun 2020 adalah 2,02 kali yang mengalami penurunan dari tahun sebelumnya yang berjumlah 3,45 kali. Penurunan nilai ITO dari tahun 2019 ini mencapai angka $38,13 \%$.

Analisis Total Modal Sendiri Terhadap Total Aktiva Sebelum dan Paska dimulainya Pandemi Covid-19

Total Modal Sendiri (TMS) terhadap Total Aset (TA) PT Matahari Department Store Tbk pada tahun 2020sebesar 9,20\% mengalami penurunan drastis dari tahun 2019 yang berjumlah 36,14\%. TMS terhadap TA dihitung denganmembandingkan total modal sendiri dengan total aktiva. Total moda 1 sendiri merupakan totalekuitas dikurangi dengan saldo laba yang belum ditentukan penggunaannya.

\section{Analisis Profitabilitas Terhadap Penjualan Sebelum dan Paska dimulainya Pandemi Covid- 19}

Net Profit Margin (NPM ) merupakan pengukuran tingkat profitabilitas penjualan yangdihasilkan. Tingkat kerugian bersih PT 
Matahari Department Store Tbk pada tahun 2020 sebesar Rp. 873,18 milyar yang sangat berbeda jauh dengan tahun sebelumnya yang mampu meraih laba sebesar 1,366 triliun. Penurunan angka laba menjadi kerugian ini mencapai angka $164 \%$ dari tahun sebelumnya. Tingginya angka kerugian ini disebabkan karena beberapa faktor utama antar lain:

a) Penurunan angka penjualan dari Rp 10,27 triliu $n$ ditahun 2019 menjadi hanya Rp. 4,83 triliun di tahun 2020, penurunan angka penjualan ini mencapai $53 \%$ dari total penjualan di tahun 2019.

b) Laba kotor perusahaannya otomatis mengikuti penurunan angka penjualan, di tahun 2019 la ba kotor PT. Matahari Department Store berjumla h 6,15 triliun sementara di tahun 2020 turun menjadi 2,83 triliun, penurunan ini hampir sama dengan penurunan angka penjualan diangka $54 \%$.

c) Biaya umum dan administrasi yang cenderung meningkat dari tahun sebelumnya, di tahun 2019 total biaya umum dan administrasi sebesa $\mathrm{r} 2,15$ triliun dan justru mengalami peningkatan sebesar 2,56 milyar di tahun 2020, meningkatnya biaya umum dan adminstrasi ini mencapai $19 \%$ sementara angka penjualan mengalami penurunan sampai dengan 53\%, biaya umum dan adminitrasi ini saja sudah secara otomatis menjadikan mengurangi $90 \%$ laba kotor yang di peroleh oleh perusahaan, sementara PT. Matahari Department Store Tbk masih harus menanggung beban penjualan ya ng angkanya mencapai 890,87 milyar rupiah.

d) Beban keuangan yang di tanggung oleh PT. Matahari Department Store Tbk juga mengalami peningkatan dari angka 56.95 milyar di tahun 2019 meningkat menjadi $81,70 \%$ ditahun 2020 , atau meningkat sebesar $43 \%$.

e) Beban lainnya yang ditahun 2019 berjumlah 928 juta meningkat sangat signifikan menjadi 216,87 milyar di tahun 2020 atau meningkat sebesar $23.270 \%$ dari tahun 2019 .

\section{Analisis Biaya - biaya Penjualan Sebelum dan Paska Pandemi Covid-19}

Pada tahun 2020 biaya pokok penjualan dan biaya langsung lainnya mencapai 2,90 milyar rupiah atau turun sebesar 54,36\% dari realisasi tahun 2019 yang angkanya mencapai 6,35 milyar rupiah.Bia ya - biaya tersebut terdiri dari biaya pokok penjualan dan beban penjualan, angka beban ini menurun karena menurunnya angka penjualan di tahun 2020 sebesar 53\% dari tahun 2019. Beban penjualan yang angkanya juga menyesuaikan dengan angka penjualan juga mengalami penurunan dari 2,23 triliun rupiah di tahun 2019 menjadi hanya 890 milyar ditahun 2020 atau turun hingga $60 \%$.

\section{Analisis Kas Terhadap Aktiva lancar Sebelum dan Paska Pandemi Covid-19}

Rasio kas (cash ratio) PT Matahari Department Store Tbk pada tahun 2020hanya sebesar18\%, angka ini mengalami penurunan sangat signifikan dari tahun sebelumnya yang mencapai angka 43\%. Rasio kas diperoleh dengan membandingkan kas dan setara kas ditambahdengan investasi jangka pendek dengan liabilitas jangka pendek.

\section{Analisis Aktiva lancar Terhadap Utang Lancar Sebelum dan Paska Pandemi Covid-19}

Current Ratio (CR) PT Matahari Department Store Tbk pada tahun 2020hanya berada diangka $56 \%$, angka ini sangat jauh berbeda dengan angka Current Ratio (CR) di tahun 2019 yang mencapai $106 \%$. Rasio lancar merupakan salah satu Liquidity Ratio yangdigunakan perusa haan untuk mengukur seberapa jauh aset lancar yang dimiliki perusahaandapat digunakan untuk melunasi lia biliti jangka pendek, dengan hasil yang ada di tahun 2020, tingkt liquiditas PT. Matahari Department Store Tbk hanya berada di angka 56\%, angka ini otomatis sangat beresiko karena jumlah asset lancar yang di miliki PT. Matahari Department Store Tbk berada di bawah total jumlah liabilities jangka pendek. Total liabilitas jangka pendek PT. Matahari Department Store Tbk di tahun 2020 berjumlah 2,85 triliun rupiah, sementara aktiva lancar yang ada hanya berjumlah 1,61 triliun rupiah.

Turunnya angka rasio Return on Investment, Return On Asset, Cash Ratio ,Current Ratio, Collection Period, Inventory Turn Over, Total Asset Turn Over, dan TotalModal Sendiri tersebut berdasarkan Du Pont Analysis dapat mendukung hipotesis penelitianbahwa setelah masa pandemi covid-19 perusahaan terbukti mengalami inefisie nsi dan penurunanyamg sangat signifikan terhadap kinerja keuangannya.

Doorasamy (2016), Kim ( 2016) dan Novita sari (2016)bahwa rata - rata capaian ROI da $n$ ROA meningkat. Namun hasil penelitian ini tidak mendukunghasil temuan Minton ( 2012), Putranto (2009) , dan Elita et al., (2015) yang ditunjukkan denganROE yang fluktuatif dan ROI yang menurun. ROE yang fluktuatif disebabkan adanya 
pertama,adanya inefisiensi pada penggunaan total cost (TC) yang tinggi namun tidak dimbangi oleh peningkatan EAT sehingga mengakibatkan NPM mengalami fluktuasi , kedua., adanyainefisiensi Total Aset sehingga mengakibatkan TATO fluktuatif. Menurut Harahap (2004)bahwa kelemahan Du Pont Analysis adalah dengan menggunakan ROI saja tidak akan dapatdigunakan untuk melakukan perbandingan antara dua masala $h$ atau lebih dengan kesimpulanyang memuaskan.

\section{SIMPULAN DAN SARAN}

Berdasarkan analisis kinerja keuangan PT Matahari Department Store Tbk sebelum dan paskaterjadinya pandemi covid-19 diawal tahun 2020 , hasil penelitian menunjukkan bahwa denga $n$ metode Du PontSystem Analysis terbukti bahwa paska terjadinya pandemi covid-19 di awal tahun 2020 kinerja keuangannya PT. Matahari Department Store Tbk menjadi tidak efisien,hal ini dibuktikan dengan besarnya penurunan angka ra sio - rasio keuangan periode sebelum Pandemi Covid19 tahun 2019 dengan paska Pandemi Covid-19 tahun 2020 .

Dengan menurunnya angka rasio Return on Investment , Return On Asset, Cash Ratio , CurrentRatio , Collection Period, Inventory Turn Over , Total Asset Turn Over, dan Total ModalSendiri tersebut dapat mendukung hipotesis penelitian bahwa setelah terjadinya pandemi covid 19 di awal tahun 2020 terbukti bahwa perusahaan mengalami inefisiensi dan penurunan kinerja keuangannya. Hasilpenelitian ini bisa dijadikan dasar penilaian kinerja keuangan karena dari hasil penelitian Doorasamy (2016) bahwa rata - rata capaian ROI danROA meningkat, namun hasil penelitian ini tidak sejalan dengan hasil temuan Elita (2015)yang ditunjukkan dengan ROE yang fluktuatif dan ROI yang menurun.

Menurut Harahap(2004) bahwa kelemahan Du Pont Analysis adalah dengan menggunakan ROI saja tidak akandapat digunakan untuk melakukan perbandingan antara dua masalah atau lebih dengankesimpulanyangmemuaskan

\section{SARAN}

Mengingat kelemahan metode DuPont Analysis tersebut maka penelitian yang akandatang metode Economic Value Added (EVA) dan MarkeValue Added (MVA) digunakanuntuk mengukur kinerja keuangan PT Matahari Department Store Tbk. Konsep EVA mampu menutupi kekurangandari analisis rasio keuangan sehingga kedua alat pengukur kinerja keuangan dapat membantupihak-pihak yang bersangkutan baik pemegang saham maupun perusahaan. Market Value Added merupakan kumulatif dari kinerja perusahaan yang dihasilkan dari berbagai investasiyang telah dilakukan maupun yang akan dilakukan. Dengan demikian peningkatan MVAmenunjukkan keberhasilan perusahaan dalam memaksimalkan kekayaan para pemegang sahamdengan alokasi sumber-sumber yang tepat. Dengan demikian MVA merupakan ukuran kinerjaeksternal perusahaan.

Walaupun belum maksimal dalam pengukuran, hasil yang di dapat sudah mampu memberikan gambaran terkait kondisi kinerja keuangan rata-rata perusahaan sektor riil, sehingga sangat tepat langkah pemerintah yang sudah dilakukan untuk menjamin kelangsungan hidup perusahaan sektor rill.

\section{DAFTAR PUSTAKA}

Anonimous.2020.PT BursaEfek Indonesia:idx.co.id

Doorasamy, Mishelle.2016. Using DuPontAnalysis to Asses The Financial Performance ofThe Top 3 JSE Listed Companies in TheFoodIndustry.Journal Investment Management and Financial Innovation . Volume 13. Issue 2:29-43.

Elita, Phrasasty I, Kertahadi, Devi, Azizah H. 2015. Analisis Kinerja KeuanganDengan Menggunakan DuPont System. Jurnal Administrasi Bisnis (JAB). Volume 2. No. 1:110.

Harahap, Syafri S. 2010. Analisis Kritis Atas Laporan Keuangan. edisi 1. Rajawali Press. Jakarta

Kim, Hak-Seon.2016. A Study of Financial Performance using DuPont Analysis in FoodDistribution Market. Journal Culinary Science and Hospitality Research. Volume 2. No 6. September.

Noviasari,Tuti.2016. Analisis DuPont System(Return on Investment, Net Profit Margin, danTotal Asset Turnover) Dalam Mengukur Kinerja Keuangan Pada PT Pelindo I .Skripsi Medan,Universitas Sumatra Utara 
Sartono, Agus. 2012. Manajemen Keuangan: Teori

Weston J. F.\& Copeland E.T. 2009.Manajemen Keuangan. Edisi 9. Jakarta: BinarupaAksara. dan Aplikasi.Edisi 4. BPFE. Yogyakarta

Sekaran,Uma.2000. Metode Penelitian untuk Bisnis Jilid 2. Edisi Jakarta. Salemba. 